\title{
ФАКТОРЫ ВОСПРИЯТИЯ ПОСТСОВЕТСКИХ СТРАН В СОВРЕМЕННОМ РОССИЙСКОМ ОБЩЕСТВЕ
}

\author{
Е.Б. Шестопал, Н.В. Смулькина
}

ШЕСТОПАЛ Елена Борисовна, доктор философских наук, профессор, зав. кафедрой социологии и психологии политики факультета политологии МГУ им. М.В. Ломоносова. Для связи с автором: shestop0505@rambler.ru; СМУЛЬКИНА Наталья Валентиновна, кандидат политических наук, младший научный сотрудник кафедры социологии и психологии политики факультета политологии МГУ им. М.В. Ломоносова. Для связи с автором: smulkina@mail.ru

Шестопал Е.Б., Смулькина Н.В. Факторы восприятия постсоветских стран в современном обществе. - Полис. Политические исследования. 2018. № 1. С. 26-44. https://doi.org/10.17976/ jpps/2018.01.03

Статья поступила в редакцию: 27.09.2017. Принята к печати: 01.11.2017

\begin{abstract}
Аннотация. Статья базируется на результатах исследования политического восприятия постсоветских стран российским гражданами, реализуемого на кафедре социологии и психологии политики факультета политологии МГУ им. М.В. Ломоносова. Анализ эмпирических данных позволил выявить ряд особенностей политического восприятия субъектного, объектного, коммуникативного, темпорального и территориального факторов. Результаты анализа позволяют говорить о различиях в воздействии отдельных факторов на рациональном и неосознаваемом уровнях восприятия, а также о различиях в конфигурации факторов влияния в восприятии каждой из постсоветских стран. В образах всех стран-соседей России преобладают положительные эмоциональные характеристики; наиболее отчетливо данная тенденция проявляется в ответах жителей российских регионов, территориально близких к изучаемым странам, с народами которых у респондентов есть личный опыт общения.
\end{abstract}

Ключевые слова: политическое восприятие; образ страны; факторы политического восприятия; постсоветские страны; политический контекст; коммуникативный фактор; территориальный фактор; темпоральный фактор; идентичность.

\section{1. ПОСТАНОВКА ПРОБЛЕМЫ}

Характер мировых политических процессов последних лет свидетельствует о том, что в международной политике происходят тектонические сдвиги, осознание которых требует значительных усилий даже от экспертов и представителей политической элиты, не говоря уже о рядовых гражданах. Как следствие, внешнеполитические представления последних оказываются подвержены влиянию мифов и стереотипов.

Такое рассогласование объективной политической и психологической реальностей ведет к внутри- и внешнеполитическим конфликтам, росту политической напряженности, взаимному непониманию людьми из разных стран. Постсоветская Россия в полной мере испытала на себе данные проблемы: для нее они обернулись ослаблением позиций в мировой политической системе, обострением конфликтов с Западом, с рядом стран-соседей. При распаде Советского Союза Россия не только потеряла часть традиционно принадлежавших ей территорий, но и столкнулась с серьезными психологическими последствиями этой геополитической трансформации внутри страны: с разрушением национально-государственной идентичности, утратой российским обществом ясной системы политических ценностей и смыслов, комплексом национальной неполноценности. 
России пришлось заново выстраивать отношения с бывшими советскими республиками, на ходу вырабатывая соответствующую стратегию. За прошедшую четверть века она неоднократно видоизменялась и лишь недавно была закреплена в "Концепции внешней политики Российской Федерации" , которая была подписана президентом В.В. Путиным 30 ноября 2016 г. Основным региональным приоритетом Концепция называет страны СНГ. Таким образом, обращение к теме восприятия этих стран российским обществом имеет вполне очевидное практическое значение, так как любая государственная стратегия малоэффективна, если не учитывает настроения общества и не получает от него поддержки.

Как показывают опросы, образы стран-соседей в глазах россиян весьма противоречивы. Так, с одной стороны, растет число тех, кто негативно оценивает позицию Украины, а друзьями нашей страны называет Казахстан и Беларусь $;$ с другой стороны, исследователи фиксируют большой запас прочности в отношениях со славянскими странами. По результатам разных исследований российского общественного мнения, врагом Украину называют от $30 \%$ до $70 \%$ опрошенных, при этом наибольшее число респондентов (47\%) предпочли бы сотрудничать именно с этой страной

Возникает вопрос: по каким критериям россияне определяют для себя страну как привлекательную, перспективную, дружественную либо враждебную? Как они оценивают потенциал той или иной страны в своих пожеланиях о сближении России с ней? Какие факторы в первую очередь определяют восприятие гражданами международных политических процессов? Мы попытаемся ответить на вопрос, под влиянием каких факторов образы стран-соседей формируются в сознании российского общества.

\section{2. ТЕОРЕТИЧЕСКИЕ ОСНОВАНИЯ ИССЛЕДОВАНИЯ}

В анализе восприятия российским обществом постсоветских стран мы опирались как на работы теоретиков международных отношений [Цыганков 2008], которые выстраивают модели, описывающие взаимоотношения России с соседями, так и на теорию политического восприятия [Психология политического восприятия... 2012: 73-81]. Первая позволяет оценить внешнеполитический контекст, а вторая - психологические механизмы восприятия россиянами стран-соседей. Кроме того, мы учитывали разработки политических географов, которые позволяют оценить пространственный фактор политического восприятия [Замятин 2003: 34-45].

\section{1. Международный контекст восприятия}

В научном дискурсе представлены различные точки зрения относительно приоритетов сотрудничества со странами ближнего зарубежья. Некоторые авторы

\footnotetext{
${ }^{1}$ Концепция внешней политики Российской Федерации 2016. - МИД России. Доступ: http://www.mid. ru/foreign_policy/news/-/asset_publisher/cKNonkJE02Bw/content/id/2542248. (проверено 30.08.2017).

${ }^{2}$ Как изменилось отношение населения Украины к России и населения России к Украине. KIIS. 11.03.2016. Доступ: http://www.kiis.com.ua/?lang=rus\&cat=reports\&id=608\&page=2 (проверено 30.08.2017); Представления о дружеских и вражеских странах. - ФОМ. 13.04.2016. Доступ: http://fom. $\mathrm{ru} / \mathrm{Mir} / 12600$ (проверено: 30.08.2017); Россияне решили, кто им враги. - Левада-Центр. 2.06.16. Доступ: http://www.levada.ru/2016/06/02/rossiyane-reshili-kto-im-vragi/ (проверено 30.08.2017); Россия и страны мира. - ФОМ. 11.07.14. Доступ: http://fom.ru/Mir/11607 (проверено 25.09.2017).

3 “Друзья” и “враги” России: эпоха санкций. - ВЦИОМ. 09.10.2014. Доступ: https://wciom.ru/index. php?id=236\&uid=115016 (проверено 21.08.2017).
} 
ставят под сомнение наличие близости с ними: "Нельзя не учитывать того, что социальная и ментальная близость народов наших стран - в прошлом... Интерес и уровень информированности как россиян, так и жителей других стран бывшего СССР о государствах-соседях сравнительно невысок” [Задорин 2008: 88].

Сам термин “постсоветское пространство”, впервые использованный А. Прозаускасом, воспринимается неоднозначно. Одни считают, что такого пространства уже нет ${ }^{4}$. Другие говорят о нем скорее как о тенденции ${ }^{5}$. Третьи определяют бывшие советские республики как единый регион "советской цивилизации", существующий и ныне ватели по-прежнему оперируют этим понятием [Ortmann 2009].

В этой связи возникает целый ряд вопросов относительно внешнеполитических установок граждан. Действительно ли былое существование в границах единого союзного государства теряет свое значение для россиян? Сохраняется ли упомянутая тенденция после присоединения Крыма к России, введения санкций против РФ и определенной консолидации российского общества последних лет, которое сопровождалась переоценкой советского прошлого? Без анализа эмпирических данных ответить на этот вопрос сложно.

Изучая внешнеполитические представления россиян, В. Петухов обращает внимание на преодоление характерного для девяностых годов синдрома самоуничижения и на появление целого ряда новых угроз и вызовов, способствующих обострению внешнеполитического “одиночества” России и стремлению усилить позицию страны в мире [Петухов 2010: 10].

В российской литературе по международной проблематике встречаются полярные суждения относительно моделей выстраивания отношений России со странами-соседями: от весьма оптимистичных до крайне пессимистичных, от узких до максимально широких [Маркедонов 2006].

Так, группа авторов из Российского совета по международным делам постулирует: "Первая задача - качественные изменения политики на постсоветском пространстве через создание привлекательных институтов экономической интеграции и коллективной безопасности, выход за рамки 'постсоветской' парадигмы через сотрудничество с внерегиональными партнерами, преодоление ограничительных линий и урегулирование конфликтов на постсоветском пространстве, наиболее острым из которых стал конфликт на Донбассе"7.

Другие аналитики, полагающие, что в постсоветский период целью РФ было сохранение авторитетного статуса для стран СНГ, отмечают, что политика России в СНГ отмечена "комплексом распада СССР", попытками загла-

\footnotetext{
${ }^{4}$ Андрусенко Л. 2009. Пространство для “бывших”. Доступ: http://4vlada.net/vneshnyaya-politika/ prostranstvo-dlya-byvshikh (проверено 30.08.2017); Малашенко А. 2012. Постсоветского пространства не существует. Доступ: http://www.newizv.ru/society/2012-06-08/164720-chlen-nauchnogo-sovetamoskovskogo-centra-karnegi-aleksej-malashenko.html (проверено 30.08.2017).

${ }^{5}$ Маркедонов C. 2009. СНГ - достаточно парадоксальная организация. - Day.Az. Доступ: https://news. day.az/politics/186599.html (проверено 25.09.2017).

${ }^{6}$ Баранов Н. Этапы развития региональной концепции в Восточной Европе. 19.06.2016. Доступ: http:// nicbar.ru/politology/study/kurs-politicheskie-transformatsii-postkommunisticheskikh-stran-tsentralnoj-ivostochnoj-evropy/239-tema-4-etapy-razvitiya-regionalnoj-kontseptsii-v-vostochnoj-evrope (проверено 30.08.2017).

${ }^{7}$ Тезисы по внешней политике и позиционированию России в мире (2017-2024 гг.). ЦСР, РСМД. Июнь 2017. Доступ: http://russiancouncil.ru/papers/Russian-Foreign-Policy-2017-2024-Report-Ru.pdf (проверено 30.08.2017).
} 
дить “беловежскую вину” [Аналитический доклад... 2001]. Не входя в детали проблем, возникших после распада СССР у России с каждой из соседних стран, отметим, что эти отношения отличаются разнообразием и наличием как общих, так и особенных противоречий.

Сегодня Россия сталкивается с необходимостью серьезного обновления внешнеполитической стратегии с учетом экзогенных факторов, влияющих на взаимоотношения стран региона. Одним из важных ресурсов эффективности нашей международной политики является учет психологического состояния российского общества, его поддержки власти на международном направлении.

Значимым фактором восприятия выступает общая история постсоветских стран и до сих пор сохраняющиеся многообразные (экономические, культурные, семейные) связи народов России и стран бывшего СССР. Для понимания ситуации и принятия взвешенных решений по развитию отношений с соседями необходим как можно более чуткий к улавливанию социальных изменений методологический инструмент анализа восприятия странами региона друг друга. Цель данной статьи - определить систему факторов, под влиянием которых в нашем обществе складываются образы стран-соседей, их конфигурацию и вес каждого из них.

Теоретический анализ международного контекста политического восприятия постсоветских стран позволяет нам высказать ряд гипотез о его влиянии на восприятие постсоветских стран в российском обществе.

Bo-nервых, можно предположить, что кризис в отношениях России с Западом из-за событий на Украине сказался на политических представлениях российских граждан о мире в целом и о своих соседях, в частности. В наибольшей степени это относится к восприятию Украины. Но и другие страны-соседи оцениваются через призму этих событий. Например, противоречивые политические заявления лидера Беларуси в данный период нередко вызывали у населения России негативные чувства.

Bo-вторых, в отношении стран-соседей наблюдается рост ностальгии по общему дому - СССР. Исследования Левада-Центра 2017 г. показали, что 53\% россиян не считают Украину заграницей, 61\% отозвались так же о Беларуси, $44 \%$ - о Грузии ${ }^{8}$.

$B$-третьих, важным фактором, влияющим на восприятие стран-соседей, стал процесс увеличения числа мигрантов, прибывающих в Россию из стран СНГ. В 2016 г. эта цифра достигла 3,8-3,9 млн чел. Восприятие наших соседей россиянами напрямую связано с успешной интеграцией мигрантов из соседних стран в российское общество.

$B$-четвертых, значимым фактором является официальная политика российского государства в отношении стран-соседей. Чем дальше от 1991 г., тем важнее для национальных интересов РФ стабилизация ситуации на сопредельной нам территории. Еще в Послании Федеральному Собранию в 2006 г. президент В. Путин заявил: "На пространстве СНГ идет непростой, но активный поиск оптимальных моделей взаимодействия. И Россия готова прямо и ясно заявить о желательном для нас конечном результате такого поиска. Это - создание оптимальной экономической системы, которая обеспечивала бы эффективное

\footnotetext{
${ }^{8}$ Россияне не считают бывшие республики СССР зарубежьем - их надо силой удерживать под контролем Москвы. - News.ru.com. 02.02.2017. Доступ: http://www.newsru.com/russia/02feb2017/levada.html (проверено 30.08.2017).
} 
развитие каждого государства"9. В официальных государственных документах был зафиксирован вектор на консолидацию сил в регионе. Однако этот проект сталкивается с множеством сложностей, что не могло не отразиться на политическом восприятии обществом бывших республик СССР.

И, в-nятых, особенно значимым в последнее время стало резко возросшее влияние на политическое восприятие мгновенного распространения информации в эпоху глобализации и интернета. Наряду с личным опытом граждан новые формы политической коммуникации формируют образы стран-соседей как через официальные государственные каналы, так и через многочисленные интернет-сети, неподконтрольные власти.

\section{2. Политико-психологическая модель восприятия стран ближнего зарубежья российским обществом}

Наряду с внешними (объектными) факторами существенное влияние на политическое восприятие оказывают субъектные, т.е. идущие от воспринимающего субъекта факторы: социально-демографические и психологические [Путин 3.0... 2015: 38-42]. Эти аспекты восприятия в международных отношениях изучены менее всего.

Из этнографической литературы известно, что с древности именно соседям люди приписывали все плохое. Как писал один из основоположников отечественной социальной психологии Б.Ф. Поршнев, для того, чтобы осознать собственную идентичность (“"мы”), люди отталкиваются от тех, кто от них отличается (“"они”) [Поршнев 1979: 35]. Соседи и являются первыми “они” для любого народа - отсюда столь важное психологическое значение восприятия стран-соседей. Отношения с соседними странами для России тем более важны, что, начиная с 2014 г., отношения со странами дальнего зарубежья сильно осложнились.

Для того чтобы выявить, как страны бывшего СССР видятся гражданами России, необходимо опереться на теоретическую модель этого процесса, описывающую психологические механизмы восприятия международными акторами друг друга. В литературе по восприятию в международной политике исследователи больше внимания уделяют механизмам искажения восприятия, страхам и рискам как факторам восприятия [Alcock, Newcombe 1970: 335-343; Buzan 1991; Смирнова 2007: 193-208].

Одна из главных методологических проблем таких исследований связана с отрывом политических образов от реальных интересов людей, что сами образы делает неустойчивыми, стереотипными и иррациональными. Возникает необходимость наряду с устоявшимися рациональными мнениями людей о других странах и собственной стране - выявить неосознаваемые компоненты их восприятия. Следует заметить, что эти неосознаваемые компоненты учитываются довольно редко [Granberg, Kasmer, Nanneman 1988: 29-46; Caplan 2001: 3-26; New Trends... 2016]. Стандартные количественные методы, в частности опросы, обычно используемые в таких исследованиях, не позволяют выявить этот слой восприятия.

В данном исследовании образы рассматриваются, с одной стороны, как отражения реальных характеристик объекта восприятия - т.е. детерминируются объектными факторами, которые служат контекстом восприятия. С другой

\footnotetext{
${ }^{9}$ Послание Президента Российской Федерации Федеральному Собранию. 2006. С. 59. Доступ: https:// rg.ru/2006/05/11/poslanie-dok.html (проверено 25.09.2017).
} 
стороны, образы стран-соседей являются проекцией ожиданий субъектов восприятия, т.е. определяются также и субъектными факторами, а значит, они будут изменяться с изменением психологических и социально-демографических характеристик воспринимающих.

Оценка пространственного фактора образов постсоветских стран позволяет выделить психологические границы восприятия, рассмотреть представления о территории, этнокультурных особенностях, оценить место стран относительно дружественных и враждебных к России территорий.

Образы страны, как и любой другой образ в сознании, не остаются статичными, они обладают динамикой. В анализе образов стран нельзя не учитывать как ретроспективные, так и перспективные аспекты образа, т.е. темпоральный фактор, так как это позволяет выделить устойчивые и изменчивые тренды восприятия других стран.

Влияние средств массовой информации на восприятие граждан в современном мире весьма существенно. Поэтому необходимо изучение влияния коммуникативных факторов на политическое восприятие.

Таким образом, задача, стоящая перед исследователями политического восприятия, двояка: необходимо описать систему факторов, их конфигурацию, а затем проинтерпретировать их, по возможности устанавливая вес каждого из системы факторов [Психология политического восприятия... 2012; New Trends... 2016].

\section{3. ХАРАКТЕРИСТИКА ИССЛЕДОВАНИЯ}

В январе-сентябре 2017 г. нами было проведено эмпирическое исследование, посвященное восприятию россиянами стран бывшего СССР. В качестве объектов изучения были выбраны семь стран: две славянские (Беларусь и Украина), три закавказские (Армения, Грузия, Азербайджан) и две среднеазиатские (Казахстан и Таджикистан) ${ }^{10}$.

Методология, использованная в изучении образов стран-соседей России, включала в себя фокусированные интервью с российскими гражданами (по 50 респондентов в случае изучения образа каждой страны, 100 в случае изучения образа Украины). В интервью был использован метод "неоконченных предложений”. Помимо интервью нами был применен метод проективного теста “Рисунок страны бывшего СССР”. Указанные методы были направлены на выявление не только рациональных, но и бессознательных аспектов образов. Поскольку нашим объектом были образы семи стран, то мы обратились к сравнительному методу, позволившему выявить сходство и отличия в политическом восприятии бывших республик СССР российским массовым сознанием.

Основой эмпирической части исследования стали 400 интервью с российскими респондентами в Москве, Санкт-Петербурге, Самарской, Костромской, Ростовской областях, в республике Дагестан и в Карачаево-Черкесии. Выбор последних трех регионов диктовался желанием проверить, как влияет на восприятие близость региона проживания к объекту исследования - двух закавказских стран - Азербайджана в Дагестане, Грузии - в Карачаево-Черкесии

\footnotetext{
10 Исследование стало частью большого проекта кафедры социологии и психологии политики факультета политологии МГУ по взаимному восприятию странами друг друга, которое проводится с 2016 г. Мы начали с ближайших соседей - бывших республик СССР. В сборе данных и их первичном анализе приняли участие аспиранты кафедры: М.М. Айбазова, В.С. Верховцев, Ш.З. Джамалудинов, К.А. Карпухина, А.А. Петлеванная, С.С. Саркисян, Э.Ш. Хаметов.
} 
и Украины - в Ростовской области. Выборка, в соответствии с правилами проведения качественных исследований, не была репрезентативна для России в целом, но была сбалансирована по полу, возрасту и образованию.

Для исследования образа стран при помощи проективных методов было собрано 375 рисуночных тестов. При интерпретации полученных рисунков внимание было сфокусировано на смысловых характеристиках стран-соседей, сценариях и сюжетах; символических объектах, встречающихся в изображении; когнитивных, эмоциональных и поведенческих особенностях восприятия. И вербальные ответы респондентов, и рисунки анализировались по параметрам силы, активности, привлекательности образа, а также по пяти смысловым блокам: образам власти, народа, политического лидера, территории, международному влиянию.

\section{4. АНАЛИЗ РЕЗУЛЬТАТОВ ИССЛЕДОВАНИЯ}

\section{1. Объектные факторы}

Говоря об объектных факторах, мы имеем ввиду прежде всего сами постсоветские государства и политический контекст восприятия, включающий как изменчивый событийный контекст, так и устойчивую политическую культуру.

Объектные характеристики стран в первую очередь определили оценки сильных и слабых сторон их образов. Самыми распространенными слабостями постсоветских стран опрошенные считают “вооруженные силь”, “экономику и финансы” и “науку и образование”. В качестве сильных сторон называли религию и культуру.

Рассогласованность характеристик встречалась в неоднозначных оценках власти и народа в образах стран-соседей. Именно на эти компоненты образа респонденты обращают внимание прежде всего. Власть в постсоветских странах обычно выглядит менее привлекательно, чем народ. Слабостью и непрофессионализмом политической элиты россияне склонны объяснять социально-экономическую неразвитость и малую роль постсоветских государств на международной арене.

Авторитарные тенденции отмечаются опрошенными во всех постсоветских странах, но оцениваются по-разному. Так, они кажутся им частью нормы в Казахстане и Беларуси, но трактуются негативно в образах Азербайджана и Таджикистана; клановость в Казахстане воспринимается как исторически оправданная: “Президент долгое время не меняется, значит власть легитимна”, “...у них “просвещенный авторитаризм””.

Образ грузинской власти был наименее привлекательным среди закавказских стран, при этом негативные оценки связывались с неустойчивостью, непредсказуемостью грузинской политической элиты, лишенной полноценного лидера. Консолидированные элиты Армении и Азербайджана, которые воспринимаются респондентами как “авторитарные" и “коррумпированные”, они чаще пытаются оправдать. В интервью упоминалось, что власть Азербайджана старается справедливо распределять ресурсы, способствует развитию страны, а элита Армении способна сохранять устойчивость даже во время конфликтов. Таким образом, при оценках власти другой страны опрошенные обращают внимание на предсказуемость и понятность этой власти в ее отношениях с Россией.

Примечательно, что международная роль страны фигурировала обычно на рациональном уровне восприятия, тогда как на неосознаваемом уровне приоритетным был образ народа - достаточно стереотипизированный, однако эмоционально заряженный. 
Большинство рассмотренных стран воспринимаются россиянами как соседи, привлекательность которых зависит от международных обстоятельств, а влияние в мире не так велико. Эмоциональная близость проявляется прежде всего в отношении Украины и Беларуси, при этом в связи с политическим контекстом Беларусь чаще других называют другом России, а Украину - врагом (см. табл. 1).

Таблица 1(Table 1)

Как Вы охарактеризуете страну по отношению к России?

(возможно более одного ответа), \%

How Would You Describe Your Country in Relation to Russia?

(more than one option possible), per cent

\begin{tabular}{|c|c|c|c|c|c|c|c|}
\hline & है & 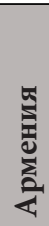 & 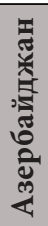 & 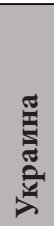 & 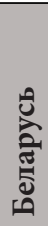 & 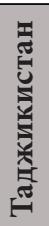 & 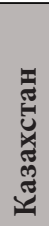 \\
\hline Как друга & 2 & 62 & 30 & 10 & 82 & 24 & 60 \\
\hline Как врага & 10 & 0 & 0 & 34 & 4 & 2 & 0 \\
\hline Как соседа & 90 & 48 & 79 & 68 & 80 & 58 & 72 \\
\hline Как партнера & 12 & 40 & 30 & 14 & 60 & 42 & 64 \\
\hline Как конкурента & 0 & 0 & 4 & 10 & 0 & 0 & 2 \\
\hline
\end{tabular}

Особенности и тип взаимоотношений с Россией определяли фокус восприятия постсоветских стран. Культурный фактор респонденты отмечали, характеризуя отношения России и Армении, политический - в российскоукраинских и российско-белорусских отношениях, географическое положение оказалось важным при восприятии Азербайджана, а трудовой потенциал проявлялся в образах Таджикистана и Украины.

Беларусь и Казахстан - государства, с которыми после распада Советского Союза Россия наиболее активно (при всех существующих проблемах) выстраивала интеграционные процессы [Чернышов 2013: 175]. В ответах на вопрос “Ошущаете ли Вы влияние этой страны в России?” проявилось более близкое, родственное отношение россиян к Беларуси, чем к Казахстану. Оценивая отношения России и Казахстана, респонденты отмечают, что Казахстан старается выступать равноправным партнером, заинтересованным прежде всего в своей выгоде, и даже стремится играть роль посредника, нейтральной стороны. Оценивая же российско-белорусские отношения, респонденты, в свою очередь, характеризовали политику Беларуси как действия именно в интересах России (“...они защищают границы России”, “приносят пользу России”). Даже отказ Беларуси соблюдать санкции в отношении Запада, являющийся нарушением союзных договоренностей, респондентами оценивается позитивно ( “...nоставляют нам дефицитные товары”). Мы имеем дело с известным феноменом, описанным поговоркой: "Не по хорошу мил, а по милу хорош”.

При рассмотрении влияния событийного контекста на первый план естественно выходят, прежде всего, украинские события. Исследование показало, что опрошенные хорошо информированы о текущем положении дел на Украине, однако испытывают затруднения в ответах на вопросы об украин- 
ском государстве и избегают объяснений своего отношения к этой стране. События, произошедшие на Украине в 2013-2014 гг., значительно повлияли на восприятие в первую очередь украинской власти. Она характеризуется как слабая, коррумпированная и непрофессиональная. Политика украинских властей в отношении России во многом определила значительное число респондентов, считающих Украину врагом. Украинский народ выглядит скорее как жертва заблуждений. Следует также отметить, что присоединение Республики Крым к Российской Федерации практически не фигурирует в ответах об этой стране. Часть респондентов изначально считала Крым российским, но у некоторых опрошенных просматривается желание психологически дистанцироваться от информации об Украине, и, как следствие, нежелание занять определенную позицию в столь болезненном вопросе.

\section{Историко-культурный фактор}

Анализ данных подтвердил наши предположения, что более тесные историкокультурные связи России с Украиной и Беларусью определяют не только большую глубину, но и большую противоречивость оценок этих государств. Активное общение россиян с украинцами и белорусами позволило им детальнее оценивать и привлекательные, и непривлекательные черты их национальных характеров.

Исследование выявило, что наряду с изменчивым событийным контекстом заметное влияние на восприятие постсоветских стран оказали некоторые константы российской политической культуры.

1. Патерналистские ориентации и установки на сильного лидера-спасителя определяют благосклонное отношение к странам с персоналистскими политическими режимами (Беларусь, Казахстан) и негативные оценки власти в странах, лишенных сильных и харизматичных лидеров.

2. Культурное наследие по-прежнему влияет на подсознательное желание россиян выступать в качестве защитников менее развитых или “ущемленных в правах" стран - “младших братьев". Отсюда, вероятно, и покровительственное отношение к менее развитым странам-соседям, и отсутствие националистических установок даже в отношении стран, находящихся сейчас в конфликтных отношениях с Россией.

3. Представления об отчужденном положении власти и народа как о норме определяют специфику прежде всего политических образов постсоветских стран. Этим, вероятно, и объясняется фокус внимания респондентов на конструктах “власти” и "народа” в образе страны. Закрытость, некомпетентность и коррумпированность власти вызывают критику в отношении постсоветских стран. Применительно к Таджикистану обращают на себя внимание упреки правящей семье в незаинтересованности и безразличии к своему народу. По мнению респондентов, власть утопает в роскоши и предается праздности. Этот пример ярко показывает важность культурных детерминант при восприятии не только “своей", но и "чужих" властей.

4. Еще одна культурная особенность российской ментальности - omcymствие традиции публичного обсуждения политики. Респонденты стесняются говорить об отношениях России с другими странами, особенно в случаях вовлеченности своей страны в конфликтную ситуацию. О противоречиях и конфликтах у нас говорить не принято.

5. Культурная близость России со славянскими странами опирается не только на общность истории и тесные контакты, но и на языковую близость. 
Логично, что в сознании респондентов более содержательно наполненными образами обладают именно Украина и Беларусь, чьи языки относятся к той же языковой группе, что и русский, схожая ситуация наблюдается в случае языковой близости народов республик Северного Кавказа из РФ с населением Азербайджана и Армении. Нельзя не заметить, что российские респонденты давали негативные оценки украинской власти в том числе и по причине ее агрессивной языковой политики.

6. Велика значимость для восприятия стран религиозного фактора. В первую очередь речь идет о религиозной общности воспринимающих и воспринимаемых, подкрепленной этнической, языковой и территориальной идентификацией. Наибольший “аванс доверия" заметен даже не в отношении Беларуси (страны с преобладающим населением православного вероисповедания), а в случае восприятия тех стран Кавказа, где присутствует большая доля христианского населения. Особенности восприятия христианских народов Закавказья (Грузии и Армении) определяли большую близость и “понятность” образов этих стран даже для московских респондентов. При восприятии Азербайджана (страны с преобладанием шиитов) наблюдалась определенная настороженность со стороны респондентов из Дагестана (сунниты). Неоднозначность оценок “шиитской ментальности” Азербайджана была особенно заметна на фоне менее противоречивых (и скорее позитивных) оценок мусульманских народов Таджикистана и Казахстана.

Таким образом, общее историческое прошлое постсоветских стран и текущие взаимоотношения с ними повлияли в первую очередь на содержательную наполненность их образов.

\section{2. Субъектные факторы}

Психологическое состояние российского общества в значительной мере влияет на формирование образов других стран, в частности, стран-соседей. Пессимистичные настроения первых постсоветских десятилетий постепенно сменяются у российских граждан чувством собственного достоинства, гордостью за страну, выступающую в качестве самостоятельного и значимого игрока в международных отношениях. Нельзя, однако, не упомянуть об определенной тревожности в отношении исследуемых стран.

В наибольшей степени субъектный фактор повлиял на противоречивое восприятие Украины. С одной стороны, в ответах отсутствовали какие-либо признаки ксенофобии и этноцентризма. С другой стороны, имели место и отстраненно обезличенные оценки Украины, вплоть до отказа отвечать на некоторые наиболее “болезненные” вопросы (о будущем, об отношениях с Россией, о территориальной целостности).

Значимым субъектным фактором, определяющим политическое восприятие, выступает самоидентификация россиян. В последнее десятилетие на постсоветском пространстве происходят заметные сдвиги по шкале идентичностей, смещение кливажа с идеологического на культурный. Диспозиция “свой - чужой” становится гораздо сложнее (“пришлые” мигранты, даже относясь к той же культурной общности, этносу и вероисповеданию, воспринимаются россиянами теперь более "чужими”). Ученые фиксируют уменьшение объема понятия "свой” и увеличение разнообразия “чужих" [Романова 2016: 163]. 
В проведенном исследовании мы видим подтверждение данной тенденции. Достаточно большое число респондентов относят постсоветские страны не к отрицательно заряженному полюсу “враг”, “конкурент”, а к обезличенной категории “сосед”. Сосед в глазах опрошенных - фигура непредсказуемая. При отсутствии ярковыраженной опасности с ним надо “держать ухо востро”, так как отношения в любую минуту могут измениться. Неудивительно, что в силу исторического контекста лидировала по данному показателю Грузия (90\%). Один из респондентов следующим образом характеризует эту страну: “Все пока тихо и спокойно. С изменой уже свыкся, а друзьями их не считаю".

Наиболее близкими народами российские респонденты называли украинцев и белорусов. Близость, однако, не является синонимом привлекательности; особенно это заметно в характеристиках народа Украины. Более позитивно выглядел образ белорусского народа, лидирующий среди всех по параметру нравственной привлекательности. Идентификация респондентов оказывает влияние на восприятие именно Беларуси. Эта страна описывается опрошенными прежде всего как дружественная и братская, и только потом как сосед и партнер. Некоторые респонденты даже отождествляли Россию и Беларусь, не видели разницы между нашими народами. Лишь в отношении белорусов не раз звучало: “они русские”, “почти как русские” “как мы”, “братья, родные”. Данная тенденция подтвердилась в проективных тестах, где Беларусь выглядела даже более привлекательно, чем в ответах на вопросы интервью.

Анализ таких социально-демографических факторов, как гендер и образование, не выявил значительных отличий в восприятии отдельных стран. Между тем возраст оказался достаточно значимым, что связано с особенностями политической социализации разных поколений: специфика личного опыта общения каждого из них заметно повлияла на восприятие. Например, формулировка “в последнее время" для респондентов разного возраста была связана с различными временными границами. Соответственно, отличалась и усредненная оценка прогноза отношения к странам-соседям (см. табл. 2). Респонденты старшего возраста чаще вспоминали распад СССР. Содержательная бедность образов в наибольшей степени была свойственна россиянам младшего поколения. У респондентов до 30 лет информация о странах бывшего СССР почерпнута в основном из СМИ.

Таблииа 2(Table 2)

Изменилось ли Ваше отношение к стране за последнее время?, \% Has Your Attitude to this Country Changed Lately?, per cent

\begin{tabular}{|l|c|c|c|}
\hline \multicolumn{1}{|c|}{ Среднее по всем странам } & до $\mathbf{3 0}$ лет & 31-55 лет & от 56 лет \\
\hline Да, изменилось радикально & 4,3 & 10,3 & 25,0 \\
\hline Да, изменилось, но незначительно & 10,9 & 15,9 & 17,0 \\
\hline Нет, почти не изменилось & 19,6 & 21,4 & 28,4 \\
\hline Совсем не изменилось & 62,3 & 45,2 & 26,1 \\
\hline Нет ответа & 2,9 & 7,2 & 3,5 \\
\hline
\end{tabular}

\section{3. Коммуникативные факторы}

Низкая информированность российских граждан о постсоветских странах, несомненно, связана со слабым освещением в СМИ. А та информация, что 
присутствует, имеет преимущественно негативный характер и способствует повышению непривлекательности образов и росту тревожности в массовом сознании. В основном респонденты обращали внимание на редкие упоминания в прессе и по телевидению стран Центральной Азии (прежде всего Таджикистана), оперировали ретро-ориентациями в отношении Грузии.

Коммуникативные каналы, с помощью которых граждане получают информацию о стране, определяют особенности ее стереотипизации. Следует признать, что характеристики постсоветских стран действительно переполнены стереотипами и символами. И если в интервью преобладали суждения о политике и государственном статусе стран, то на подсознательном уровне внимание уделялось обычно стереотипам о народе, религии, культуре и образе жизни. Можно предположить, что стереотипы в отношении постсоветских стран формировались в результате неодинакового влияния разных коммуникативных источников. Так, стереотипизация образов Украины и Беларуси прежде всего связана с влиянием современных СМИ; в образах Казахстана и Таджикистана большую роль сыграли давние советские стереотипы, а в отношении стран Закавказья преобладают стереотипы 1990-х годов. Информационная повестка СМИ значительно влияет на властный компонент образов стран, на представления россиян о международной роли государств.

Проведение исследования не только в Москве, но и в пограничных регионах позволило выявить значительное влияние личного опыта на информированность, эмоциональную оценку и содержательную глубину ответов. Те респонденты, которые признавали, что лично сталкивались с представителями постсоветских стран, имеют с ними личные связи или посещали страну (в юности и в последнее время), выказывали большую заинтересованность в судьбе государств, их ответы были содержательно развернутыми и позитивными. Информированность же, как правило, порождала большую амбивалентность ответов, респонденты с большим энтузиазмом давали и позитивные, и негативные характеристики. Чаще всего вопрос личных контактов возникал при оценках Казахстана (посещение данной страны особенно способствовало повышению привлекательности ее образа).

Личные контакты российских граждан с представителями постсоветских стран были связаны не только с посещением нашими гражданами соседних территорий и родственными связями, но и с присутствием граждан постсоветских стран на российской территории. Значимым здесь видится рассмотрение вопроса восприятия россиянами мигрантов из ближнего зарубежья. Исследование не зафиксировало выраженной неприязни к мигрантам из азиатских стран: так, в характеристиках выходцев из Таджикистана часто звучали позитивные оценки профессиональных качеств (трудолюбивые, выносливые работяги).

Современные средства массовой информации продолжают оставаться важнейшим каналом информирования рядовых граждан о других странах. Информация, почерпнутая респондентами из СМИ, придает образам преимущественно политическую окраску и формирует когнитивно бедные и стереотипные представления о государствах. Россияне мало знают о современных деятелях культуры, искусства, спорта и науки стран бывшего СССР. Называя их представителей, респонденты чаще всего упоминали именно политических деятелей (преимущественно из Украины, политическая жизнь которой активно освещается в СМИ). 
Рассматривая значимость коммуникативного фактора, необходимо отметить публичную активность глав государств. Персонификация имиджа страны способствует переносу восприятия лидера на отношение к стране и ее народу. Данная тенденция была особенно заметна в образах Беларуси и Казахстана, при этом в российских СМИ Назарбаев не имеет такого негативного образа, как Лукашенко: белорусская власть оценивалась как непредсказуемая и зависимая от личных интересов правителя.

\section{4. Темпоральные факторы}

Большинство респондентов отмечали, что их отношение к постсоветским странам в последнее время значительно не изменилось. Лишь в отношении Украины, Грузии и Азербайджана данная тенденция не прослеживается. Именно на образы этих стран темпоральный фактор оказал наибольшее влияние. При этом если в случае Грузии и Азербайджана отношение к ним ухудшилось (38 и 22,6\%), то в случае Украины позиция не столь однозначна: у одних респондентов отношение улучшилось, у других - ухудшилось, и их число примерно одинаково. Однако ухудшение отношения коснулось украинской власти, а не народа.

Образы стран во временной перспективе формируются вокруг значимых исторических событий. Эта тенденция наиболее заметна в образах Грузии, Казахстана и Таджикистана. В случае Грузии темпоральные границы в оценках респондентов удивительным образом расширяются, относя к "последнему времени" весь постсоветский период. При этом большинство респондентов, отмечающих ухудшение отношения к Грузии, связывало его с грузиноосетинским конфликтом, приходом к власти М. Саакашвили и нестабильностью страны.

Темпоральные границы другого рода были характерны для образов азиатских стран, также находящихся сейчас в “информационном вакууме”. В случае восприятия Казахстана и Таджикистана образы чаще были связаны с СССР и сопровождались идеализацией прошлого. Странами достаточно благополучными и стабильными в будущем станут, по мнению респондентов, Казахстан и Беларусь (см. табл. 3). В мрачных тонах чаще всего рисуют будущее Украины и Таджикистана.

Таблица 3 (Table 3)

Как Вы представляете себе будущее этой страны?, \%

How Do You Imagine the Future of This Country?, per cent

\begin{tabular}{|c|c|c|c|c|c|c|c|}
\hline $\begin{array}{c}\text { Эмоциональный знак } \\
\text { образа в будущем }\end{array}$ & 总 & 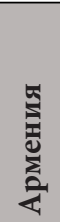 & 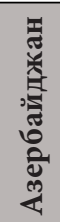 & 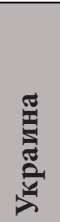 & 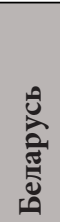 & 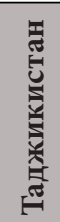 & 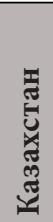 \\
\hline Положительный & 30 & 50 & 53 & 34 & 66 & 30 & 80 \\
\hline Отрицательный & 10 & 8 & 8 & 40 & 2 & 16 & 4 \\
\hline Нейтральный & 32 & 10 & 37 & 12 & 16 & 22 & 12 \\
\hline Амбивалентный & 6 & 8 & 2 & 14 & 4 & 20 & 0 \\
\hline Нет ответа & 22 & 24 & 0 & 0 & 12 & 12 & 4 \\
\hline
\end{tabular}




\section{5. Пространственные факторы}

Возможность территориальных потерь постсоветских стран в будущем предположили немногие респонденты. Они обращали внимание преимущественно на спорные территории и непризнанные республики. Самыми нестабильными опрошенным в перспективе видятся Украина, Грузия и Азербайджан. И на рациональном, и на бессознательном уровнях восприятия территориальные аспекты образов постсоветских стран выглядят стабильно. Реже проявлялась тенденция к сужению существующих границ. Установка на расширение территорий для респондентов не характерна. Респонденты верят в полную потерю Грузией возможности влиять на непризнанные республики. Вероятность выхода Нагорного Карабаха из состава Азербайджана видят $10 \%$ респондентов, в то же время $23 \%$ полагают, что его территория может увеличиться. Оценивая будущее Украины, 18\% опрошенных признают возможность потери ею территорий ЛНР и ДНР, а $52 \%$ респондентов отмечают опасность распада этой страны (см. табл. 4).

Таблица 4 (Table 4)

Как Вы думаете, могут ли измениться границы этой страны в обозримом будущем?, \%

Do You Think That the Borders of This Country Can Change in the Foreseeable Future?, per cent

\begin{tabular}{|c|c|c|c|c|c|c|c|}
\hline & 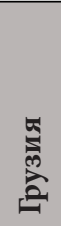 & 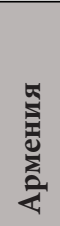 & 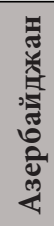 & 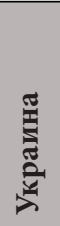 & 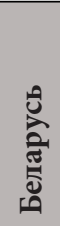 & 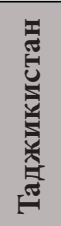 & 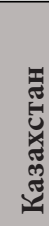 \\
\hline Территория увеличится & 0 & 8 & 24 & 0 & 4 & 2 & 0 \\
\hline Территория уменьшится & 14 & 2 & 6 & 18 & 0 & 2 & 0 \\
\hline Территория не изменится & 74 & 88 & 68 & 28 & 92 & 90 & 98 \\
\hline Страна распадется на части & 12 & 0 & 2 & 52 & 4 & 6 & 2 \\
\hline Нет ответа & 0 & 2 & 0 & 2 & 0 & 0 & 0 \\
\hline
\end{tabular}

Наибольшая значимость территориальных компонентов образа страны была заметна при изучении бессознательного уровня восприятия Украины и Армении. Сюжеты рисунков чаще связаны с Россией и странами Запада. Также на неосознаваемом уровне в образах постсоветских стран территория имела меньшее значение, чем в образах других (не постсоветских) стран. Территория стран бывшего СССР в оценках респондентов упоминалась в тематической связке с природой, народом, культурой, советским единством, не неся при этом политического смысла. Данная тенденция, возможно, объяснима существованием в массовом сознании стереотипа “ненастоящего зарубежья".

Не менее значимым аспектом влияния территориального фактора на процесс восприятия является пограничное положение территории относительно нашей страны. Наша гипотеза о более позитивном отношении к ближайшим соседям подтвердилась лишь частично. С одной стороны, ответы респондентов граничащих территорий были более содержательными и полными, что связано с лучшей информированностью респондентов об объекте восприятия. С другой стороны, такие респонденты не всегда воспринимают их позитивнее в сравнении с теми регионами, которые от объекта восприятия на- 
ходятся дальше. Так, например, рисунки Украины, сделанные респондентами из Ростовской области, чаще содержали в себе признаки тревоги и страха, чем московские рисунки. В ответах ростовских респондентов чаще упоминались национализм и ксенофобские настроения украинской власти.

\section{ВЫВОДЫ}

Прежде всего следует подчеркнуть, что тезис о том, что социальная и ментальная близость стран бывшего СССР осталась в прошлом, не разделяется российскими респондентами. Более того, наши данные показывают определенный рост ностальгии по советскому прошлому и рисуют образ стран-соседей как “ненастоящего зарубежья". Народы этих стран под влиянием последних событий в мире воспринимаются как “свои”. В ответах респондентов не было проявлений этноцентризма и ксенофобии в отношении к мигрантам, высокомерия и имперских амбиций, которые нередко приписывают россиянам. Даже в отношении Украины - страны, с которой сейчас мы имеем не самые простые отношения, - респонденты испытывают не враждебность, а скорее сочувствие к ее многострадальному народу. В целом следует отметить, что образы всех стран-соседей имеют положительные эмоциональные характеристики. Особенно это заметно в тех регионах, которые находятся близко от изучаемых стран и в которых у респондентов есть личный опыт общения.

Это можно считать серьезным резервом для наращивания экономической, культурной и иной интеграции постсоветского пространства. Несмотря на разногласия между государствами, потенциал их исторического единства не исчерпан.

Сказанное не означает, что представления российского общества о странах бывшего СССР так и остались на уровне пропагандистских клише прежних лет. Образы бывших советских республик, а ныне независимых стран, существенно отличаются друг от друга в глазах россиян.

Предложенная нами факторная модель позволила выявить различия в степени воздействия отдельных факторов на рациональном и бессознательном уровнях восприятия.

Объектные факторы оказали самое серьезное влияние на образы странсоседей. Степень близости опрошенных различна в отношении народов разных стран: большая - с Украиной и Беларусью, меньшая - с Грузией.

Субъектные факторы оказались менее значимыми для восприятия стран-соседей: если гендер и образование не оказывают серьезного влияния, то возраст влияет существенно.

Фактор культурно-исторической близости определяет большую эмоциональную близость Украины и Беларуси для жителей Москвы и Центральной России, а для респондентов из северокавказских республик России - большую близость со странами Закавказья. Фактор религиозной общности определяет близость с Грузией, Арменией и Беларусью как с христианскими странами.

В политическом восприятии постсоветских стран значимость пространственного фактора менее значима, чем для других стран. Их территория не воспринимается как политическое “пространство”.

Темпоральный фактор имел различную глубину в разных странах. Так, для образов Украины и Беларуси решающей оказалась текущая инфор- 
мация, на образы стран Закавказья больше воздействуют стереотипы 1990-х, а Казахстан и Таджикистан воспринимаются больше под влиянием советских стереотипов.

Рассмотрение влияния коммуникативного фактора показало наличие запроса общества на более внятную информационную политику России в отношении постсоветских стран. В целом снижается осведомленность россиян о современной жизни стран бывшего СССР. Сокращается представленность этих стран в российском информационном пространстве.

Как показало наше исследование, восприятие других стран во многом формируется под влиянием психологического состояния российского общества. Когда мы позитивно оцениваем свою собственную страну, то и оценки других стран становятся намного позитивнее.

Аналитический доклад "Итоги деятельности СНГ за 10 лет и задачи на перспективу”. - Дипломатический вестник. № 12. 2001. Доступ: http://www.mid.ru/ integracionnye-struktury-prostranstva-sng/-/asset_publisher/rl7Fzr0mbE6x/content/ id/571396 (проверено 30.08.2017).

Берендеев М.В. 2007. Калининградцы в поисках идентичности. - Социологические исследования. № 4. С. 127-132.

Бызов Л., Петухов В. 2008. Постсоветское пространство: культурные и социальные связи. - Мониторинг общественного мнения. № 3 (87). С. 79-86.

Горшков М.К. 2007. Российская идентичность в социологическом измерении: аналитический доклад. - Институт социологии РАН. Доступ: http://www.isras.ru/ analytical_report_Ident0.html (проверено 21.08.2017).

Горшков М.К., Петухов В.В. 2016. Внешнеполитические ориентации россиян в контексте вызовов современной глобальной политики. - Политическая наука перед вызовами глобального и регионального развития: научное издание. Под ред. О.В. Гаман-Голутвиной. М.: Аспект Пресс. С. 606-634.

Задорин И.В. 2008. Интеграционные ориентации населения стран СНГ: динамика и перспективы. - Интеграция в Евразии: социологическое измерение. Вып. 2. М.: ИНЭС. С. 61-89.

Замятин Д.Н. 2003. Политико-географические образы российского пространства. - Вестник Евразии. № 4. С. 34-45.

Конфисахор А.Г., Медведева В.В. 2011. Психологический анализ геополитических процессов. - Вестник СПбГУ. Сер. 12. Вып. 1. С. 36-42.

Маркедонов С. 2006. Россия Владимира Путина и СНГ: миссия без цели. Неприкосновенный запас. № 6. Доступ: http://www.intelros.ru/index.php?newsid=285 (проверено 30.08.2017).

Митрофанова С.Ю. 2016. Образ “страны-врага” и “страны-друга” в представлениях современных студентов технического вуза. - Экономика и социология. № 2. С. 19-23.

Петухов В.В. 2010. Внешнеполитические приоритеты массового сознания россиян. - Социологические исследования. № 11. С. 4-13.

Поршнев Б.Ф. 1979. Социальная психология и история. 2-е изд. М.: Наука. 235 с.

Психология политического восприятия в современной России. Под ред. Е.Б. Шестопал. 2012. М.: РОССПЭН. 432 с.

Путин 3.0. Власть и общество в новейшей истории России. Под ред. Е.Б. Шестопал. 2015. М.: АРГАМАК-Медиа. 420 с. 
Романова А.П. 2016. Образ “чужого” на постсоветском пространстве. Каспийский регион: политика, экономика, культура. № 4. С. 159-166.

Россия на новом переломе: страхи и тревоги. Под ред. М. Горшкова, Р. Крумма, В. Петухов. 2009. М.: Альфа-М. 159 с.

Смирнов А.А. 2015. Страна и Образ ее будущего: методологический аспект. Стратегические приоритеты. № 3. С. 34-43.

Смирнова А.Г. 2007. Восприятие угрозы в международных отношениях: в поисках теоретических оснований. - Политическая экспертиза. Т. 3. № 4. С. 193-208.

Чернышов Ю.Г. 2013. Белоруссия и Казахстан: восприятие народов и политических лидеров в России. - Вестник КемГУ. № 2. Т. 3. С. 175-179.

Чернышов Ю.Г. 2015. Пограничное пространство как барьер между утопическими и реальными образами стран и регионов. - Дневник АШПИ. № 33. С. 76-81.

Alcock N.Z., Newcombe A.G. 1970. The Perception of National Power. - The Journal of Conflict Resolution. Vol. 14. No. 3. P. 335-343. https://doi.org/10.1177/002200277001400304

Buzan B.1991. People, States and Fear: an Agenda for International Security Studies in the Post-Cold War Era. Bolder: Lynne Rienner Publishers, Inc. 393 p.

Caplan B. 2001. Rational Ignorance versus Rational Irrationality. - Kyklos. Vol. 54. No. 1. P. 3-26. https://doi.org/10.1111/1467-6435.00138

Granberg D., Kasmer J., Nanneman T. 1988. An Empirical Examination of Two Theories of Political Perception. - Political Research Quarterly. Vol. 41. No. 1. P. 29-46. https://doi. org/10.1177/106591298804100103

New Trends in Russian Political Mentality: Putin 3.0. Ed. by E.B. Shestopal. Lanham, Maryland: Lexington Books. 2016. 414 p.

Ortmann S. 2009. Russian and post-Soviet Foreign and Security Policy. University of Sussex, Spring term 2009/2010. URL: https://www.sussex.ac.uk/webteam/gateway/ file.php?name $=$ russian-and-post-soviet-foreign-and-security-policy\&site $=12$ (accessed 25.08.2017).

DOI: $10.17976 /$ jpps/2018.01.03

\title{
FACTORS OF POLITICAL PERCEPTION OF POST-SOVIET COUNTRIES IN CONTEMPORARY RUSSIAN SOCIETY
}

\author{
E.B. Shestopal ${ }^{1}$, N.V. Smulkina ${ }^{1}$ \\ ${ }^{1}$ Lomonosov Moscow State University. Moscow, Russia
}

SHESTOPAL Elena Borisovna, PhD, Dr. Sci. (Philos.), Prof., Head of the Department of Sociology and Psychology of Politics, Faculty of Political Science, Lomonosov Moscow State University. Email: shestop0505@rambler.ru; SMULKINA Natalia Valentinovna, Cand. Sci. (Pol. Sci.), Junior Researcher, Department of Sociology and Psychology of Politics, Faculty of Political Science, Lomonosov Moscow State University. Email: smulkina@mail.ru

Shestopal E.B., Smulkina N.V. Factors of Political Perception of Post-Soviet Countries in Contemporary Russian Society. Polis. Political Studies. 2018. No. 1. P. 26-44. (In Russ.) https://doi.org/10.17976/jpps/2018.01.03

Received: 27.09.2017. Accepted: 01.11.2017

\begin{abstract}
This article discusses factors of political perception of post-Soviet countries on the basis of the recent study. Authors trace the influence of factors that determine images of post-Soviet countries in Russian society. Analysis of empirical data made it possible to identify the relevant objective, subjective, temporal, territorial, communicative, and cultural factors. Results of the study allow to conclude about varying degree of influence of individual factors on the rational and unconscious levels of perception. Object of perception had the most serious impact on the images of neighboring countries. Strong is the influence of political culture that contributes to the perception of post-Soviet countries as "we". Socio-
\end{abstract}


demographic factors differentiate in their influence on the images of post-Soviet countries: education and gender have low influence, while age is quite important. Psychological condition of our own society appeared to be one of the most important factors. In the images of Ukraine and Belarus the influence of mass media is strong, while in the images of Kazakhstan, Tajikistan, a great role is played by the historical and cultural factor and personal experience. The images of all neighboring countries have positive emotional characteristics. This is especially noticeable in those Russian regions that are close to the boundaries and in which respondents have personal experience of communicating with the peoples of these countries.

Keywords: political perception; country image; factors of political perception; post-Soviet states; political context; communicative factors; space (territorial); temporal factors; identity.

\section{References}

Alcock N.Z., Newcombe A.G. The Perception of National Power. - The Journal of Conflict Resolution. 1970. Vol. 14. No. 3. P. 335-343. https://doi.org/10.1177/002200277001400304

Berendeev M.V. Kaliningraders Are Looking for Identity. - Sotsiologicheskie Issledovaniya. 2007. No. 4. P. 127-132. (In Russ.)

Buzan B. People, States and Fear: an Agenda for International Security Studies in the Post-Cold War Era. Bolder: Lynne Rienner Publishers, Inc. 1991. 393 p.

Byzov L., Petukhov V. Post-Soviet Space: Cultural and Social Ties. - The Monitoring of Public Opinion: Economic and Social Changes. 2008. Vol. 87. No. 3. P. 79-86. (In Russ.)

Caplan B. Rational Ignorance versus Rational Irrationality. - Kyklos. 2001. Vol. 54. No. 1. P. 3-26. https://doi.org/10.1111/1467-6435.00138

Chernyshov Yu.G. Belarus and Kazakhstan: The Perception of Their Peoples and Political Leaders in Russia. - Bulletin of Kemerovo State University. 2013. Vol. 2. No. 3. P. 175-179. (In Russ.)

Chernyshov Yu.G. Boundary Space as a Barrier Between Utopian and Real Images of Countries and Regions. - Dnevnik ASHPI. 2015. No. 33. P. 76-81. (In Russ.)

Gorshkov M., Petukhov V. Vneshnepoliticheskie orientatsii rossiyan v kontekste vyzovov sovremennoi global'noi politiki [Foreign Policy Orientations of Russians in the Context of the Challenges of Modern Global Politics]. - Politicheskaya nauka pered vyzovami global'nogo i regional'nogo razvitiya: nauchnoe izdanie. Pod red. O.V. Gaman-Golutvinoi [Political Science Before the Challenges of Global and Regional Development: A Scientific Publication. Ed. by O.V. Gaman-Golutvina]. Moscow: Aspect Press Publ. 2016. P. 606-634.

Gorshkov M. Russian Identity in the Sociological Dimension: An Analytical Report. 2007. (In Russ.) URL: http://www.isras.ru/analytical_report_Ident0.html (accessed 21.08.2017).

Granberg D., Kasmer J., Nanneman T. An Empirical Examination of Two Theories of Political Perception. Political Research Quarterly. 1988. Vol. 41. No. 1. P. 29-46. https://doi.org/10.1177/106591298804100103

Konfisahor A.G., Medvedeva V.V. Conflicts as Geopolitical Processes: Psychological Analysis and Its Solving out Ways. - Vestnik of Saint Petersburg University. Series 12. 2011. No. 1. P. 36-42. (In Russ.)

Markedonov S. Putin's Russia and CIS: Mission Without Purpose. - Neprikosnovennyj zapas. 2006. No. 6. (In Russ.) URL: http://www.intelros.ru/index.php?newsid=285 (accessed 30.08.2017).

Mitrofanova S. The Image of the "Enemy Country" And "Friend Country" in the Representations of Modern Students of a Technical University. - Economics and Sociology. 2016. No. 2. P. 19-23. (In Russ.)

New Trends in Russian Political Mentality: Putin 3.0. Ed. by E.B. Shestopal. Lanham, Maryland: Lexington Books. 2016. 414 p.

Ortmann S. Russian and post-Soviet Foreign and Security Policy. University of Sussex, Spring term 2009/2010. URL: https://www.sussex.ac.uk/webteam/gateway/file.php?name=russian-and-post-soviet-foreign-and-security-policy\&site $=12$ (accessed 25.08.2017).

Petukhov V.V. Foreign Policy Priorities in the Consciousness of Contemporary Russians. - Sotsiologicheskie Issledovaniya. 2010. No. 11. P. 4-13. (In Russ.)

Porshnev B.F. Social'naya psihologiya i istoriya [Social Psychology and History]. 2nd ed. Moscow: Nauka. 1979. 235 p. (In Russ.)

Psihologiya politicheskogo vospriyatiya v sovremennoj Rossii. Pod red. E. Shestopal [The Psychology of Political Perception in Contemporary Russia. Ed. by E. Shestopal]. Moscow: ROSSPEN. 2012. 432 p. (In Russ.)

Putin 3.0.: Obshchestvo i vlast'v noveyshey istorii Rossii. Pod red. E.B. Shestopal [Putin 3.0.: Society and Authority in the Contemporary History of Russia. Ed. by E. Shestopal]. Moscow: ARGAMAK-MEDIA. 2015. 420 p. (In Russ.) 
Results of CIS Activity for 10 Years and Tasks for the Future. - Diplomaticheskij vestnik. 2001. No. 12. (In Russ.) URL: http://www.mid.ru/integracionnye-struktury-prostranstva-sng/-/asset_publisher/rl7Fz$\mathrm{r} 0 \mathrm{mbE6x} /$ content/id/571396 (accessed 30.08.2017).

Romanova A.P. The image of "Alien" at the Post-Soviet space. - The Caspian region: Politics, Economics, Culture. 2016. No. 4. P. 159-166. (In Russ.)

Rossiya na novom perelome: strahi i trevogi. Pod red. M. Gorshkova, R. Krumma, V. Petukhova [Russia on a New Turn: Fears and Worries. Ed. by M. Gorshkov, R. Krumm, V. Petukhov]. Moscow: Al'fa Publ. 2009. 159 p. (In Russ.)

Smirnov A.A. The Country and the Image of Her Future: Methodological Aspect. - Strategic Priorities. 2015. No. 3. P. 34-43. (In Russ.)

Smirnova A.G. Studies of Threat Perception in International Relations: in Search for Theoretical. Political Expertise: POLITEX. 2007. Vol. 3. No. 4. P. 193-208. (In Russ.)

Zadorin I.V. Integratsionnye orientatsii naseleniya stran SNG: dinamika i perspektivy [Integration Reference Points of the CIS Population: Dynamic and Prospects]. - Integratsiya v Evrazii: sotsiologicheskoe izmerenie. Vyp. 2 [Integration in Eurasia: Sociological Dimension]. Moscow: INES. 2008. P. 61-89. (In Russ.) Zamyatin D. Politico-Geographical Images of the Russian Space. - Acta Eurasica. 2003. No. 4. P. 34-45. (In Russ.) 